\title{
CAUSE AND CORRELATION IN LANGUAGE CHANGE
}

Malte Rosemeyer (KU Leuven)

Freek Van de Velde (KU Leuven)

51st Meeting of the Societas Linguistica Europaea Tallinn, 30 August 2018 


\section{CAUSATION IN HISTORICAL LINGUISTICS}

- What counts as a cause in historical change?

- Consider morphosyntactic change: changes in usage contexts of a construction A might be caused by restructuring of constructional networks, for instance the rise or loss of a competing construction B

- Empirical problem: correlation does not imply causation

- We will present a statistical method that helps to distinguish correlation and cause in language change 


\section{A toy example}

1. INTRO

2. Clefting IN BP

3. DATA

4. GRANGER

CAUSALITY

5. RESULTS

6. CONClusion

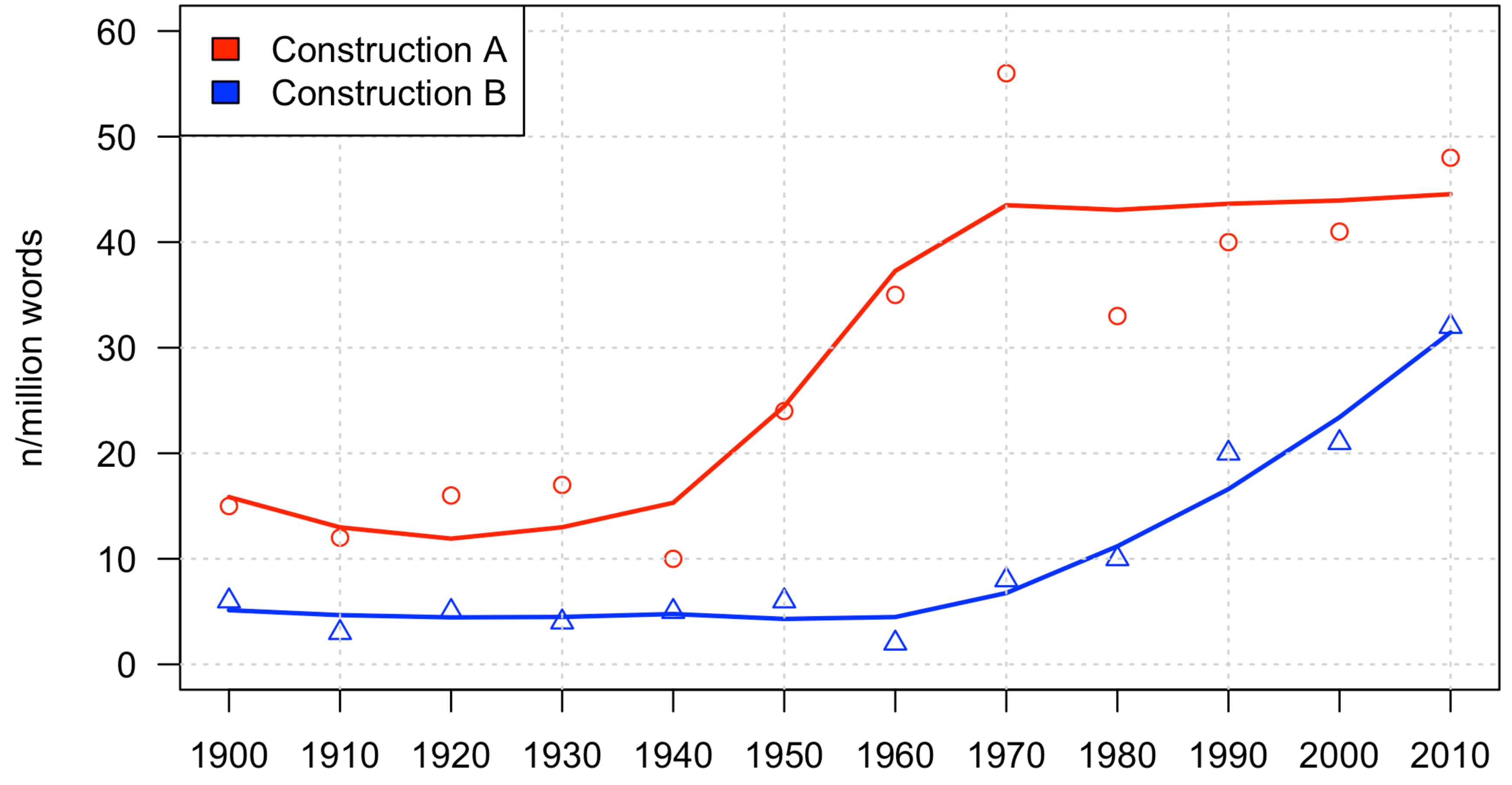

Time 


\section{INVERSE CORRELATION BETWEEN INFLECTION AND WORD ORDER}

1. INTRO

2. CLeFTING IN $\mathrm{BP}$

3. DATA

4. GRANGER CAUSALITY

5. RESULTS

6. CONCLUSION
“(...) one of the most banal and familiar (but slippery) precepts in all of linguistics, to wit, that there is some kind of functional tradeoff between morphology and syntax. It is often said, but very difficult to prove, that word order tends to be rigid where morphology is absent, but free where morphology is relatively luxuriant."

"What we see here is an interaction between two ways of signalling the noun-modifier relation, i.e. NP constituency - by adjacency (...), or by morphological binding, (case and/or gender/number agreement). Both principles are universal, but they can play against each other, so that when one is violated, the other becomes obligatory." Givon (2001a: 282)

"There is a correlation between rigidity of word order and absence of a morphological means of distinguishing $\mathbf{A}$ from $\mathbf{O}$, even if it is not true that rigid word order is necessary if $\mathrm{A}$ and $\mathrm{O}$ are to be distinguished by order." Mallinson \& Blake (1981)

"Turning to the relationship between word order and morphological marking, the analyzed data reveal that neither the presence of agreement nor of case marking is a sufficient condition for flexible order, nor does rigid order entail the absence of either form of morphological marking. There is nonetheless a relationship between the two phenomena, namely flexible order tends to be accompanied by the presence of overt agreement and / or case marking and lack of agreement and/or case marking tends to be accompanied by rigid or restricted order." Siewierska (1998: 525-526) 


\section{WHAT CAUSED WHAT?}

1. INTRO

2. CLEFTING IN $\mathrm{BP}$

3. DATA

4. GRANGER

CAUSALITY

5. RESULTS

6. CONCLUSION

f

KU LEUVEN
- Different suggestions in the literature:

- Loss of case system caused the emergence of fixed word order (SVO): Foulet (1930: \$50), von Wartburg (1965: 129), Rheinfelder (1967: 45), Harris (1978: 49), Faarlund (2001: 1718), Bentz \& Christiansen (2013: 55-56)

- Rise of fixed word order caused the loss of the case system Bourciez (1967: §559)

- No direct causation Lerch (1934: 267-271), Schösler (1973: 251-254, 2001a: 277-278), Detges (2009) 


\section{CLEFT-WH INTERROGATIVES IN BRAZILIAN PORTUGUeSE (BP)}

- Historical increase in the usage frequency of BP cleft-wh interrogatives Lopes Rossi (1993; 1996; 1998), Duarte (1992), Fontes (2012a; 2012b), Kato \& Ribeiro (2005; 2009), De Paula (2015; 2016), Rosemeyer (to appear)
(1) a. Onde
você foi?
ExSitu
where
you go.PST.PFV.3SG
b. Onde
que você foi?
Cleft 


\section{DEClaRATIVE CLEFTS IN BP}

1. INTRO

2. CLEFTING IN $\mathrm{BP}$

3. DATA

4. GRANGER

CAUSALITY

5. RESULTS

6. CONCLUSION

f
- The rise in the usage frequency of cleft- $w h$ interrogatives in turn coincided with a rise of the usage frequency and syntactic productivity of cleft sentences of the 'that' type Kato \& Ribeiro (2009)

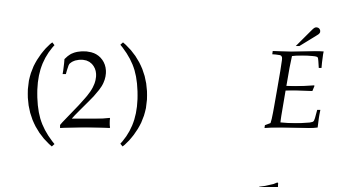
$a$
Maria que chegou.
be.PRS.PFV.3SG DET.F.SG Mary that arrive.PST.PFV.3SG 'It is Mary who arrived' 


\section{WORD ORDER CHANGES IN BP}

2. CleFTING IN $\mathrm{BP}$

3. DATA

4. GRANGER

CAUSALITY

5. RESULTS

6. CONCLUSION
- Increase in 'that'-clefts is caused by word order changes, in particular the loss of V2 Kato \& Ribeiro (2009: 123)

- Possible word orders in Class. Port.: Galves \& Paixão Sousa (2017)
(3) Christo Senhor nosso, disse
a seus
Discipulos

Christ Master POSS.1 say.PRS.PFV.3SG to POSS.3PL disciples 'Christ our Lord, said to his Disciples...'

(4) Mártires os chama-vam os companheiros

Martirs them call-PST.IPFV.3PL DET.M.PL fellows 'Their fellows called them martirs'

(5) ou odespedaça-vam, ou the pun-ham $o$ fogo either it smash-PST.IPFV.3PL or to-it PUT.PST.IPFV.3PL DET.M.SG fire '(they) either smashed it or put fire to it' 
1. INTRO

2. Cleffing IN $\mathrm{BP}$

3. DATA

4. GRANGER CAUSALITY

5. RESULTS

6. CONCLUSION

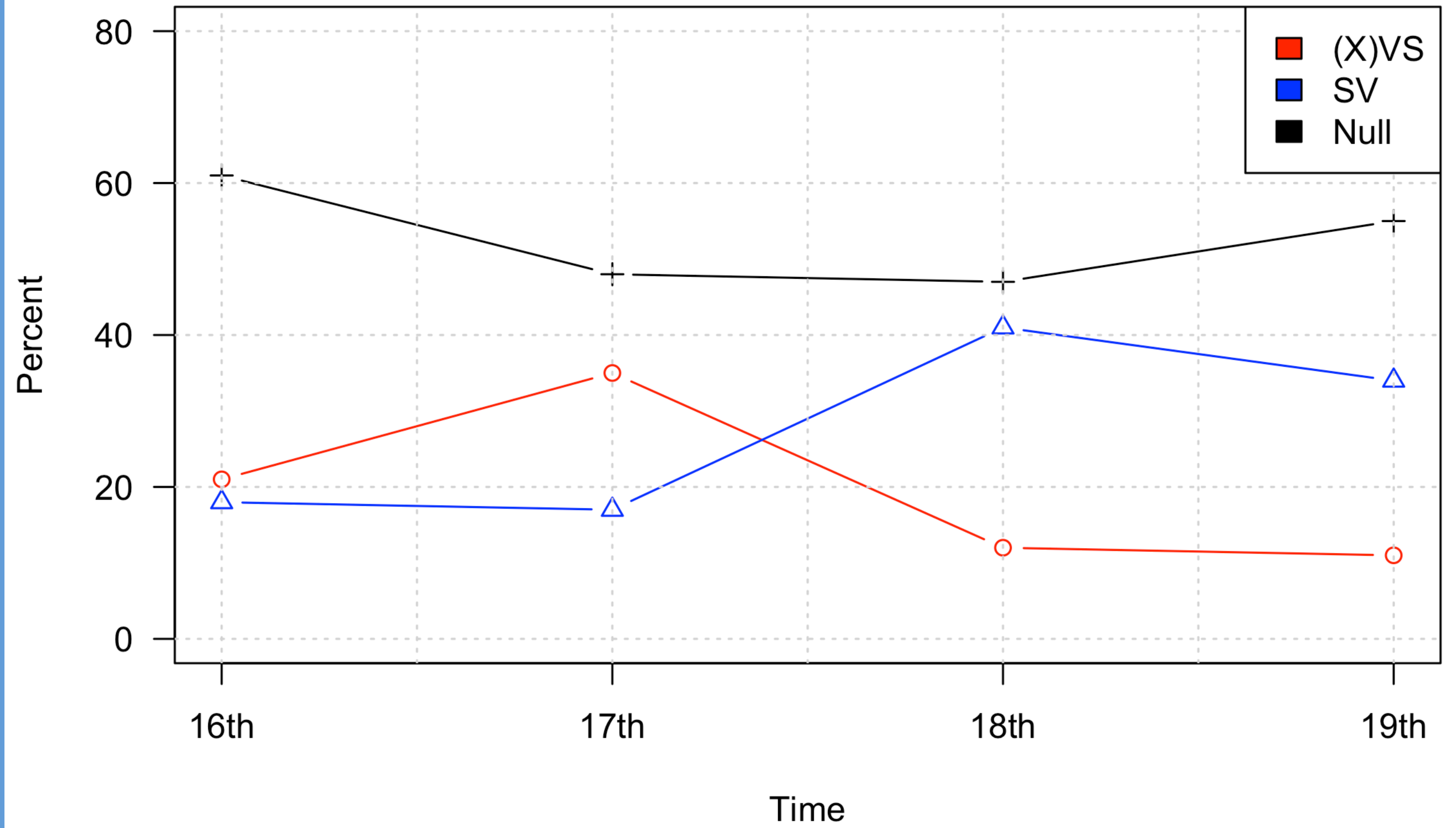

data from Galves \& Paixão Sousa (2017: 157) $(n=34,293)$ 


\section{POSSIBLE HYPOTHESES}

1. INTRO

2. CleFting IN $\mathrm{BP}$

3. DATA

4. GRANGER

CAUSALITY

5. RESULTS

6. CONCLUSION

f

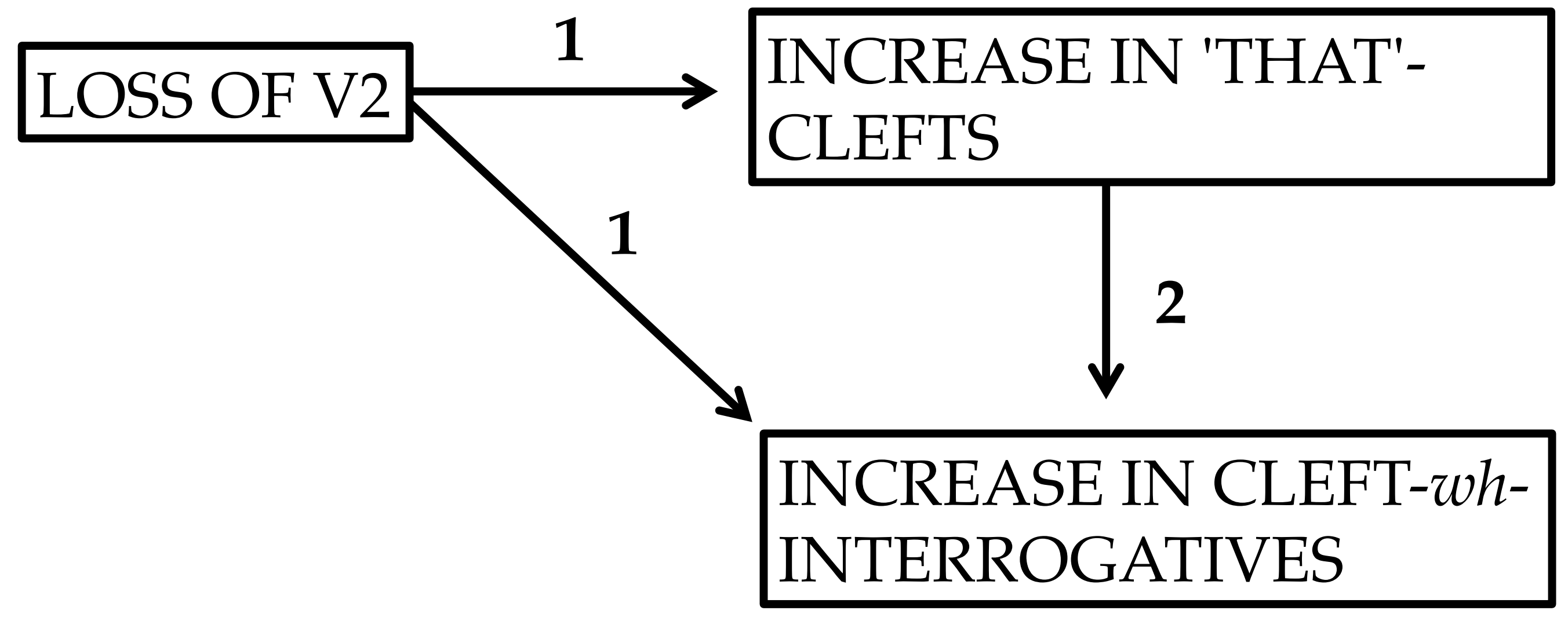

H1: Loss of V2 -> more 'that'-clefts -> more cleft-wh interrogatives

$\mathrm{H} 2$ : Loss of $\mathrm{V} 2 \rightarrow>$ more clefting in general

H3: Loss of V2 -> more cleft-wh interrogatives 


\section{POSSIBLE HYPOTHESES (INVERTED)}

1. INTRO

2. Clefting IN $\mathrm{BP}$

3. DATA

4. GRANGER

CAUSALITY

5. RESULTS

6. CONCLUSION

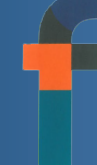

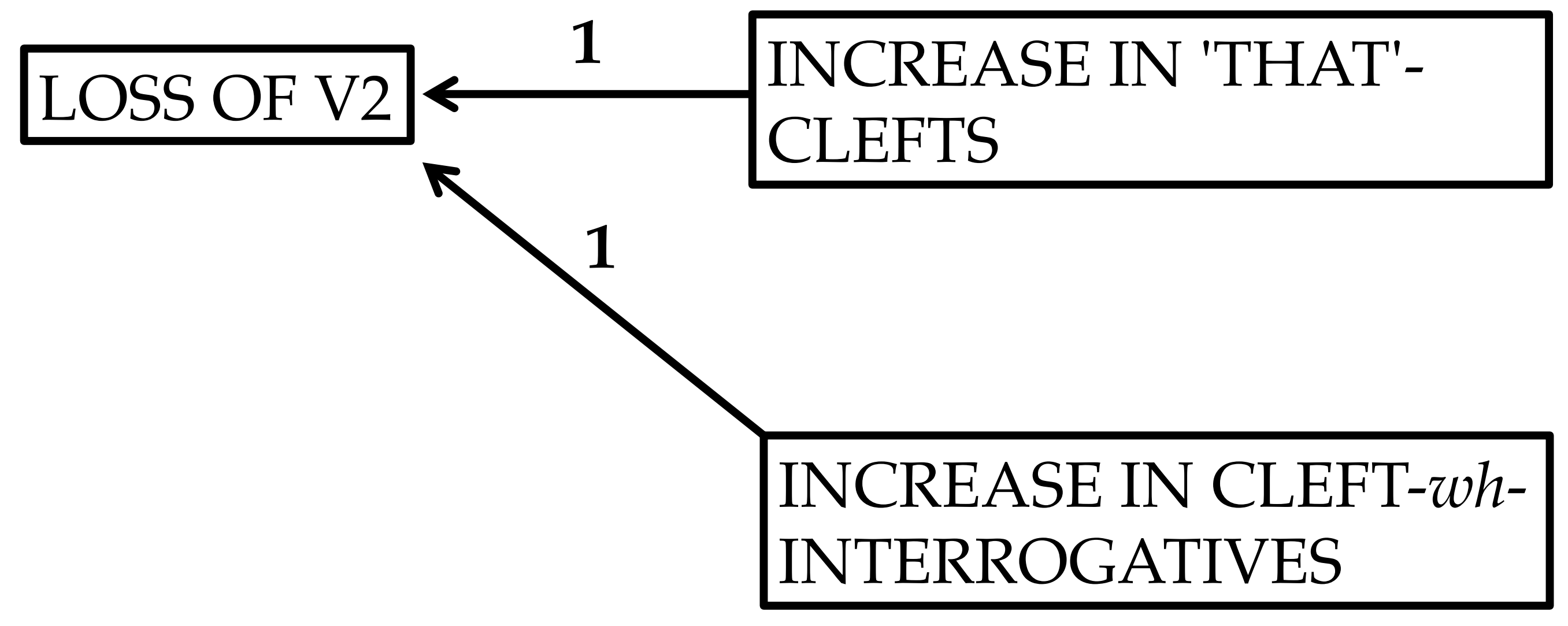

H4: More 'that' clefts $->$ loss of V2

H5: More clefting in general -> loss of V2

H6: More cleft-wh interrogatives -> loss of V2 


\section{MOTIVATIONS FOR H1-3 (NON-INVERTED)}

- Word order was used to mark information structure ${ }_{\text {Galves \& }}$ Paixão (2017), Galves \& Gibrael (fc.)

- null subject means an "unmarked" information structure

- the preverbal position is reserved for "prominent elements of various kinds" --> topicalization

- postverbal subjects are interpreted as "familiar" or "continuing" topics

(6) Em várias partes das fronteiras fizeram os castelhanos in several parts of.the borders make.PST.PFV.3PL DET.F.PL Castilians fumo smoke 'The Castilians made fire on several places along the border' 


\section{IMPLICATIONS OF THE CHANGE: 'THAT'-CLEFTS}

INTRO

2. CLEFTING IN $\mathrm{BP}$

3. DATA

4. GRANGER

CAUSALITY

5. RESULTS

6. CONCLUSION

f
- Loss of word order as a marker of information structure meant that speakers had to mark information structure some other way

- While Romance cleft sentences are usually considered markers of contrastive focus or presentational markers, it has recently been suggested that the main function of cleft sentences is to ensure topic continuity Hedberg/Fadden (2007), Dufter (2009), Roggia (2009), De Cesare et al. (2016)

- 'That'-clefts may thus have arisen as a compensation strategy for the loss of postverbal subject use in declaratives 


\section{IMPLICATIONS OF THE CHANGE: WH-QUESTIONS}

2. CleFTING IN $\mathrm{BP}$

3. DATA

4. GRANGER

CAUSALITY

5. RESULTS

6. CONCLUSION
- The function of subject postposition in wh-interrogatives in Classical Portuguese seems similar to the function in declaratives ("familiar" or "continuing" topics)

(7) Xanto. Esopo, que escrito e esse, que ai tens?

Esopo what document be.PRS.3SG this, that there have.PRS2SG? 'Esopo, what is this document that you are holding there?' Esopo. É a carta da menina

be.PRS.3SG the letter of.the girl

'It's the letter from the girl'

Xanto. Como vai ela com o ler?

How go.PRS.3SG she with the read 'How is her reading going?' (lit. How does she go with the reading?) 


\section{IMPLICATIONS OF THE CHANGE: WH-QUESTIONS}

1. INTRO

2. CleFTING IN $\mathrm{BP}$

3. DATA

4. GRANGER

CAUSALITY

5. RESULTS

6. CONCLUSION

- Early cleft-wh interrogatives are typically used in contexts in which the question proposition is highly accessible, leading to a discourse-continuing interpretation

(8)
Ana. Então diz-ei
ao Sr. Francisco
que aceit-o.

So say-PST.PFV.1SG to.the Mr. Francisco that accept.PRS.1SG 'So I told Mr. Francisco that I accept'

Carlos.Que é que aceit-ais?

What be.PRS.3SG that accept.PRS.2SG

'What is it that you accept?'

Ana. Bast-a só que êle o saiba.

suffice-PRS.2SG only that he it know.PRS.SBJ.3SG

'Only he needs to know that'

(Comédia sem título, Martins Pena, 1848, t5978) 


\section{IMPLICATIONS OF THE CHANGE: WH-QUESTIONS}

1. INTRO

2. CleFTING IN $\mathrm{BP}$

3. DATA

4. GRANGER

CAUSALITY

5. RESULTS

6. CONCLUSION
- Similarly to 'that'-clefts, cleft-wh interrogatives may have arisen as a compensation strategy for the loss of postverbal subject use in wh-interrogatives 


\section{CORPUS}

1. INTRO

2. CleFting IN BP

3. DATA

4. GRANGER

CAUSALITY

5. RESULTS

6. CONCLUSION

KU LeUVEN
- Self-compiled corpus of over 3.2 million words from European and Brazilian Portuguese theater texts between 1736 and 2016 (Rosemeyer to appear) 


\section{DATA COLLECTION}

1. INTRO

2. Clefting IN $\mathrm{BP}$

3. DATA

4. GRANGER

CAUSALITY

5. RESULTS

6. CONCLUSION
- Wh-interrogatives: $n=21372$ cases, $n=1883$ cleft- $w h$

- SV word order: all instances of a personal pronoun followed by a verb (identified via regex) --> $n=26501$

- Declarative 'that'-clefts: all instances of present-tense 'that'clefts (é X que P) --> n=808 


\section{Interrogative clefts}

1. INTRO

2. Cleffing IN $\mathrm{BP}$

3. DATA

4. GRANGER

CAUSALITY

5. RESULTS

6. CONCLUSiOn

\section{KU LEUVEN}
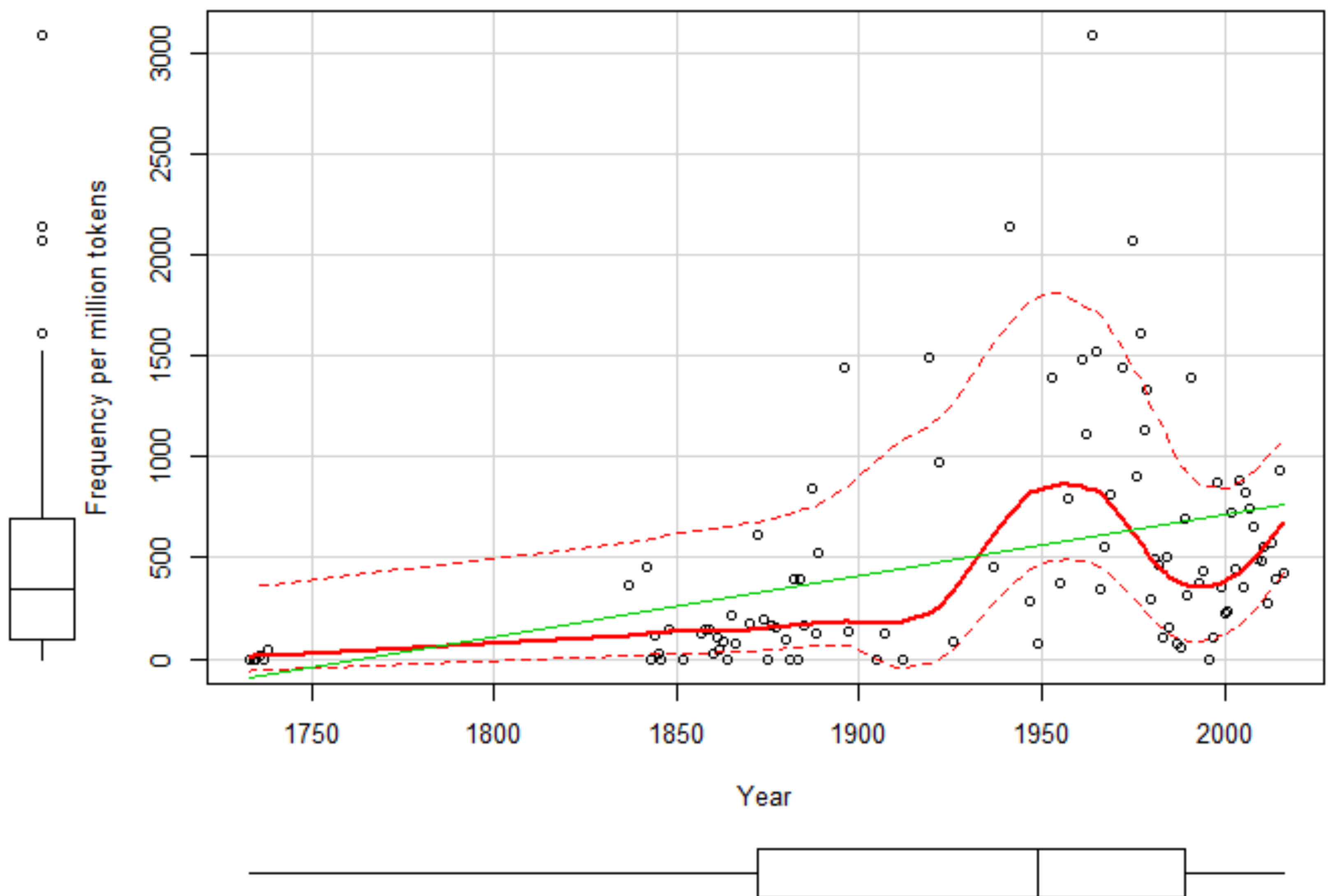


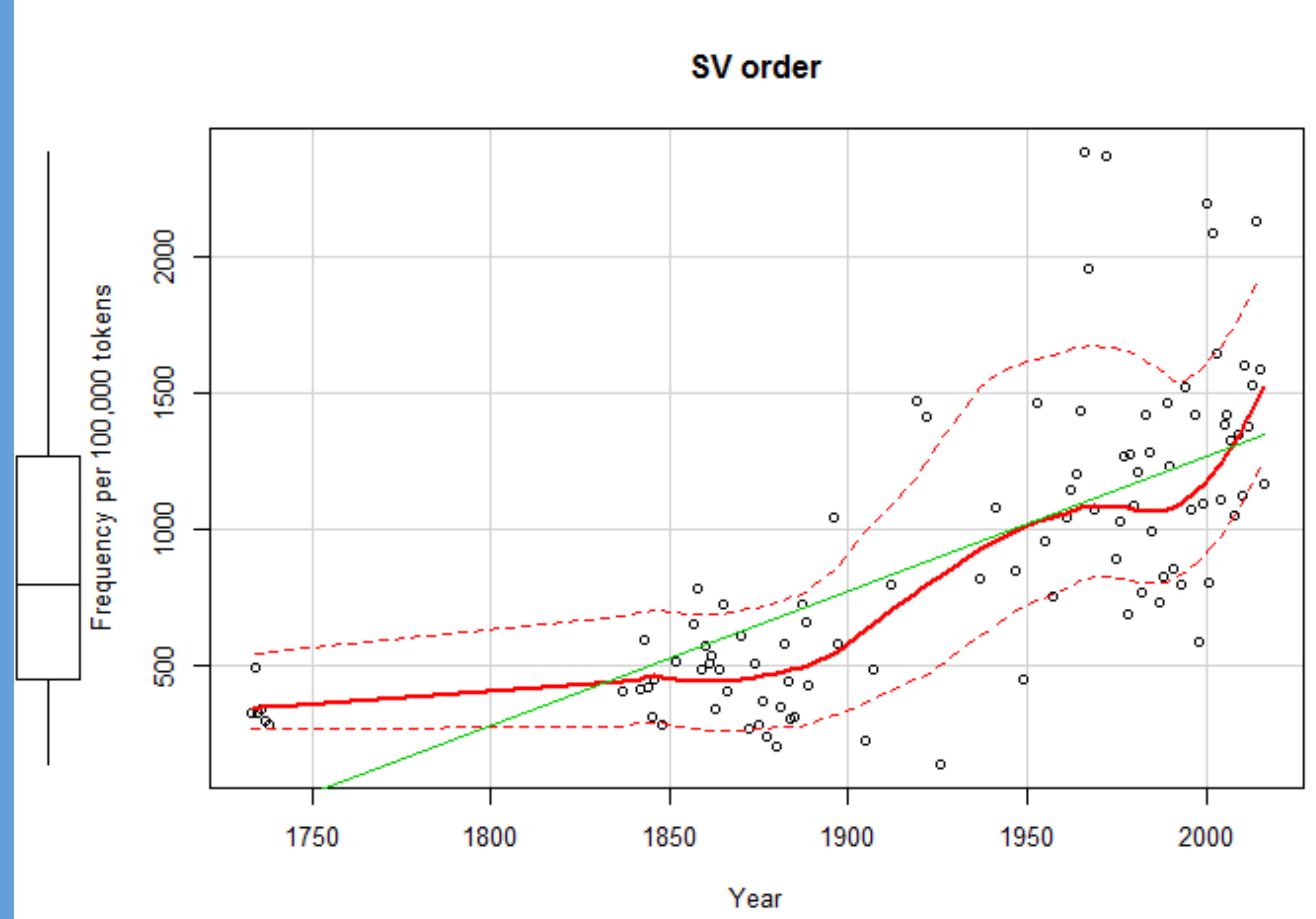

KU LeUVEN 


\section{Declarative clefts}

1. INTRO

2. Cleffing IN BP

3. DATA

4. GRANGER

CAUSALITY

5. RESUltS

6. CONCLUSiOn

so

KU LEUVEN

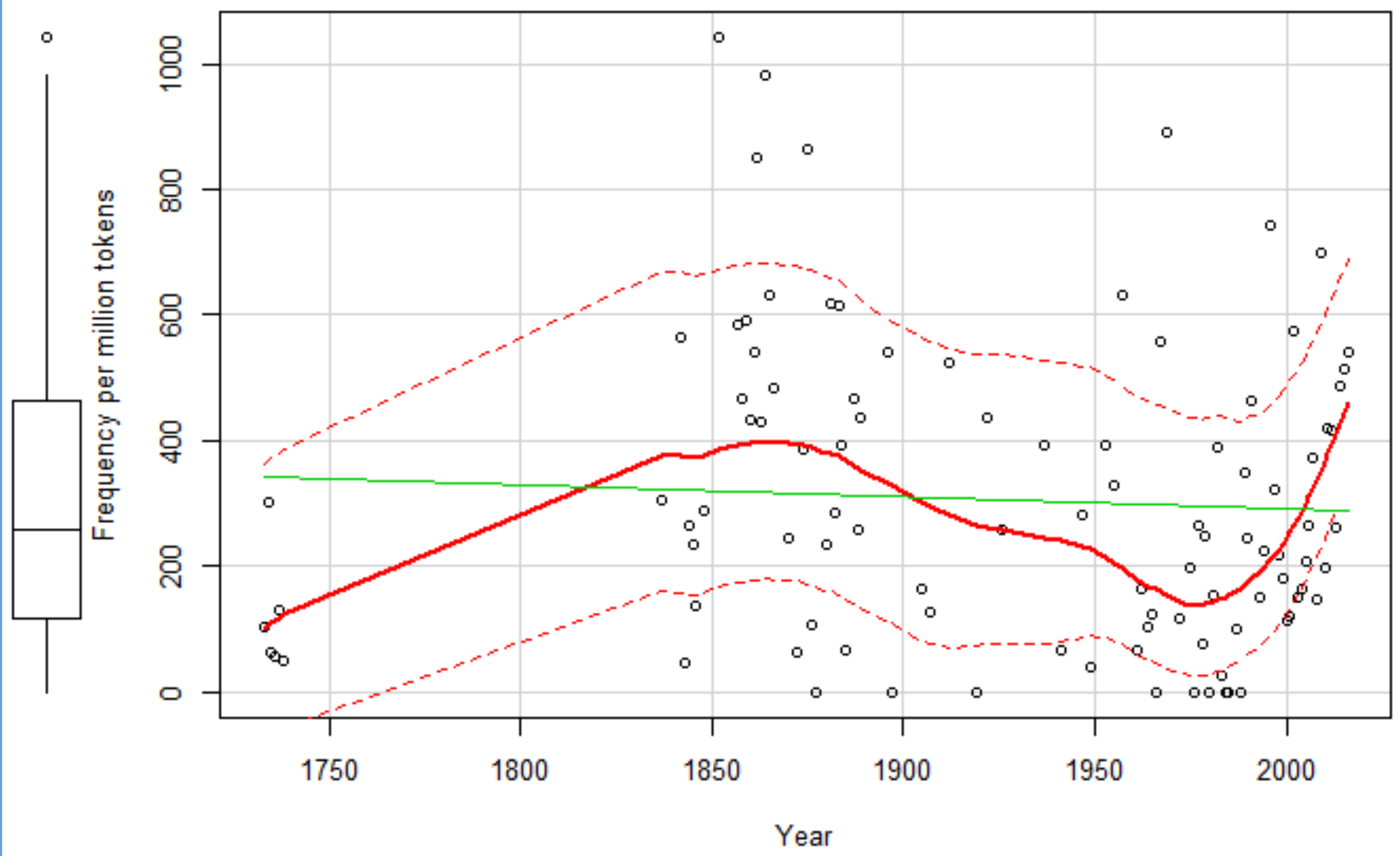




\section{TIME SERIES ANALYSIS}

- Historical linguistics often makes use of TIME as an independent variable, in correlation studies or in multiple regression

- While this gives good results, it flouts the assumption of independence of datapoints

- Often high degree of 'autocorrelation'. This leads to an underestimation of the standard error

- We need techniques that take care of the autocorrelation due to consecutiveness of time measurements.

- One of these techniques is Time Series Analysis (see Baayen et al. 2018 for an application to experimental data, and Van de Velde \& Petré, forthc. for an application to historical linguistics). 


\section{TIME SERIES ANALYSIS - GRANGER CAUSALITY}

1. INTRO

2. CLEFTING IN BP

3. DATA

4. GRANGER CAUSALITY

5. REsUlts

6. CONCLUSION

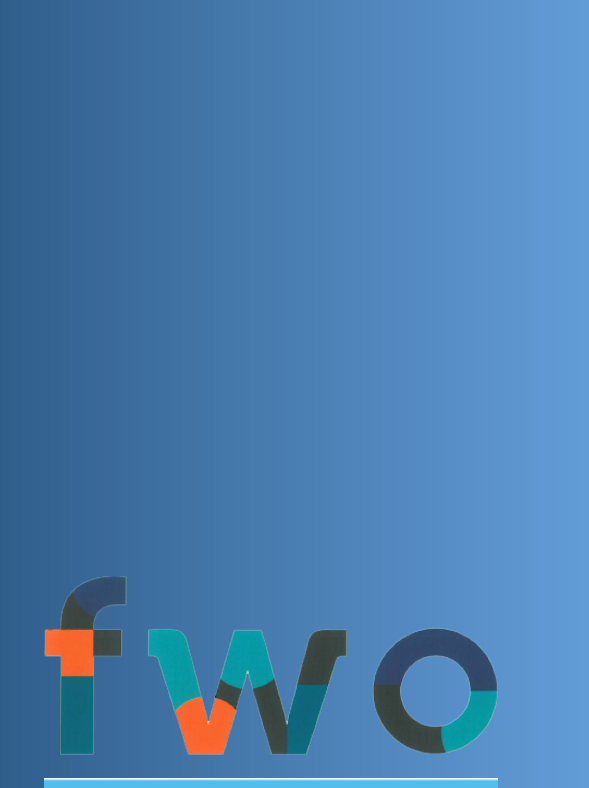
KU LEUVEN
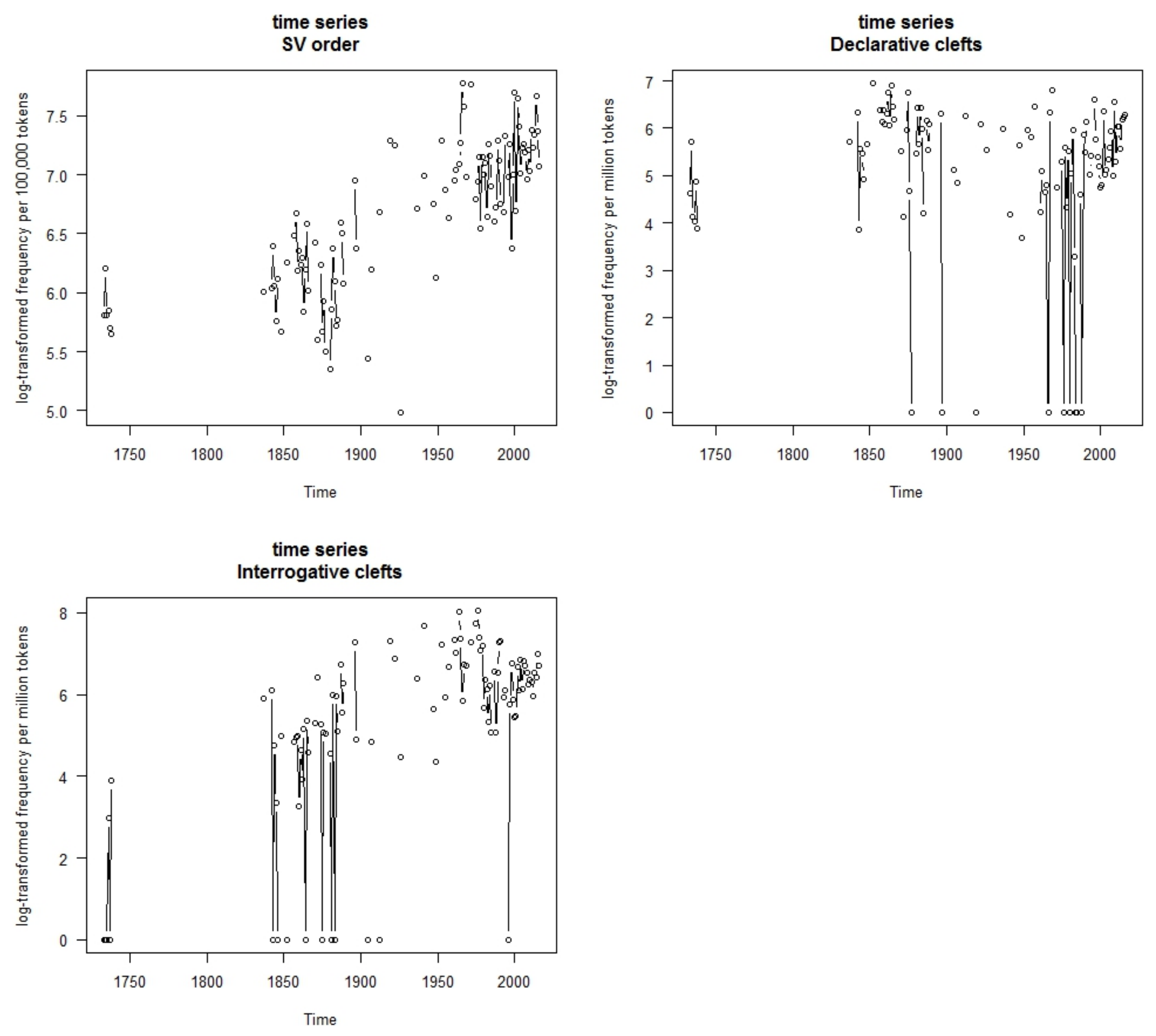


\section{TIME SERIES ANALYSIS - GRANGER CAUSALITY}

\section{INTRO}

2. Clefting IN $\mathrm{BP}$

3. DATA

4. GRANGER CAUSALITY

5. RESULTS

6. CONCLUSION

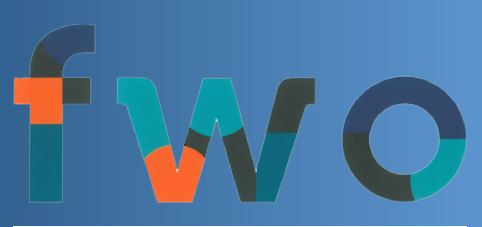

KU LEUVEN
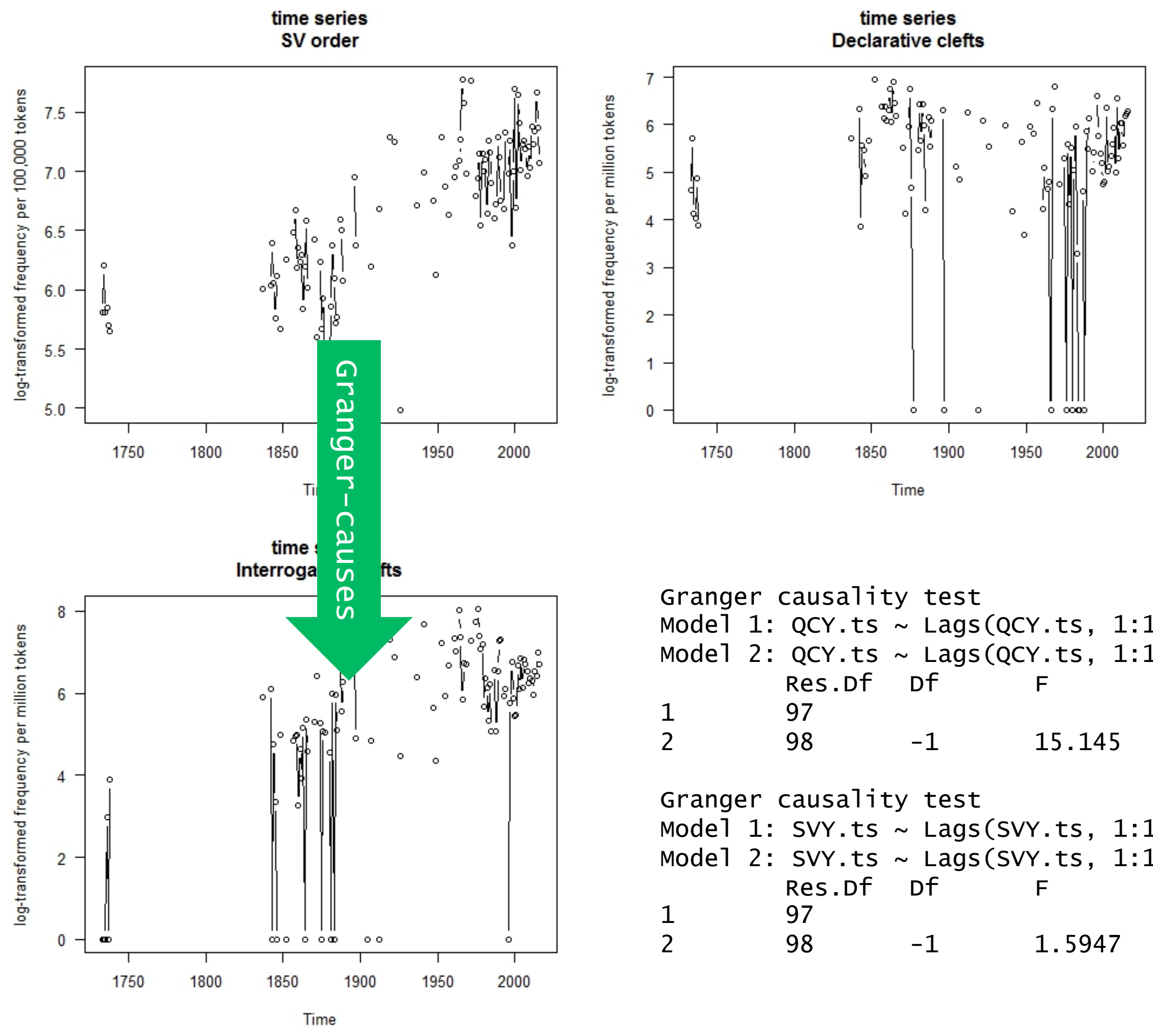

Granger causality test

Mode1 1: QCY.ts Lags (QCY.ts, 1:1) + Lags (SVY.ts, 1:1) Mode1 2: QCY.ts Lags (QCY.ts, 1:1)

$$
\begin{array}{lllll}
1 & 97 & & & \\
2 & 98 & -1 & 15.145 & 0.0001826 * * *
\end{array}
$$

Granger causality test

Mode1 1: SVY.ts $\sim$ Lags (SVY.ts, 1:1) + Lags (QCY.ts, 1:1)

Mode1 2: SVY.ts Lags (SVY.ts, 1:1)

$\begin{array}{lllll} & \text { Res.Df } & \text { Df } & F & \operatorname{Pr}(>F) \\ 1 & 97 & & & \\ 2 & 98 & -1 & 1.5947 & 0.2097\end{array}$ 


\section{TIME SERIES ANALYSIS - GRANGER CAUSALITY}

\section{INTRO}

2. Clefting IN $\mathrm{BP}$

3. DATA

4. GRANGER CAUSALITY

5. RESULTS

6. CONCLUSION

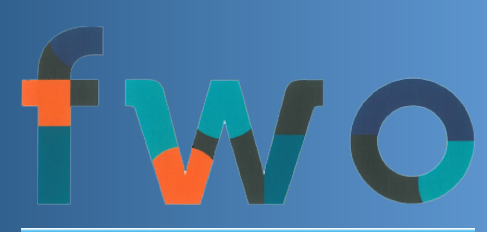

KU LEUVEN
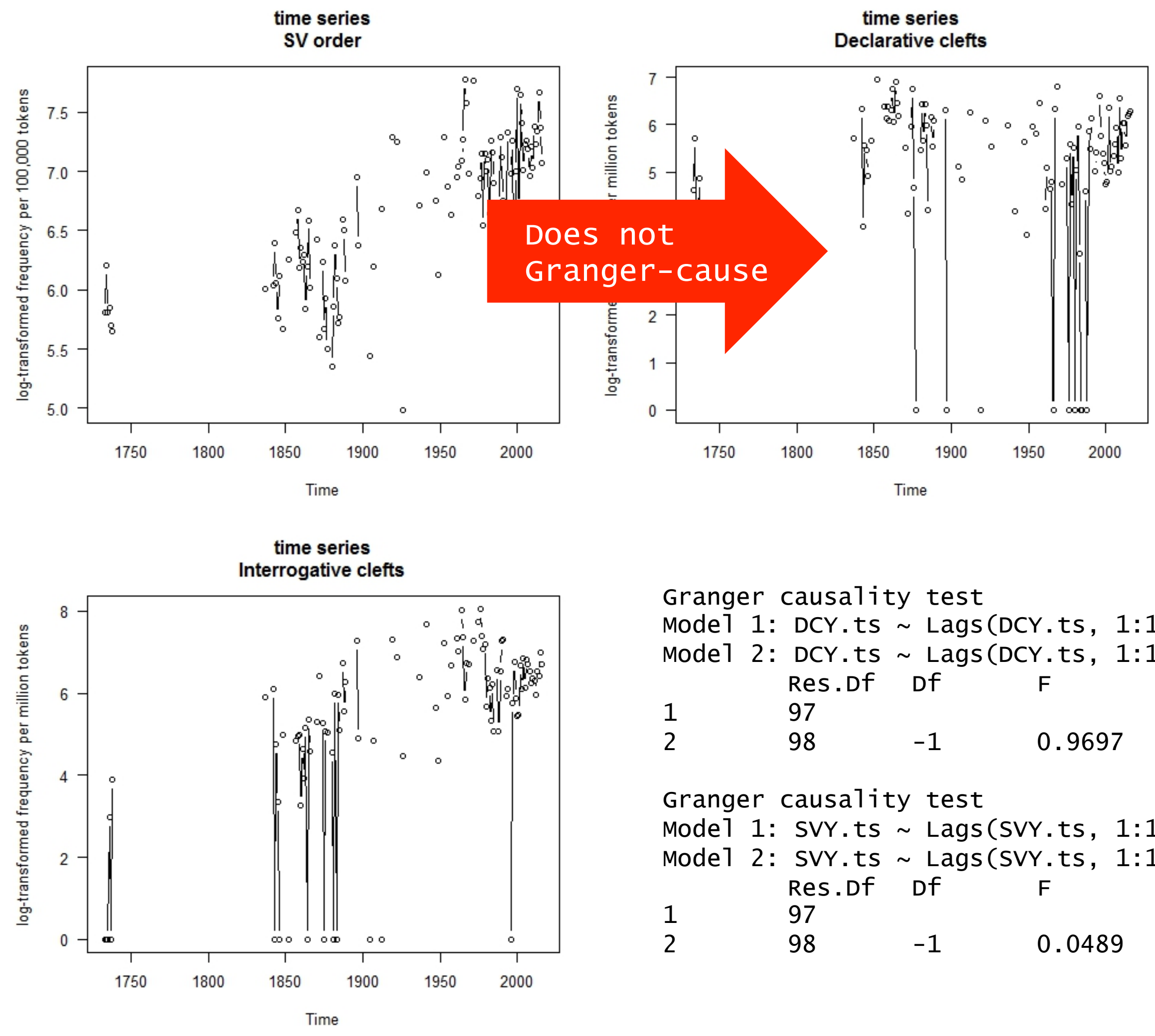

Granger causality test

Mode 1 1: DCY.ts Lags (DCY.ts, 1:1) + Lags (SVY.ts, 1:1) Mode1 2: DCY.ts $\sim \operatorname{Lags}($ DCY.ts, 1:1)

$\begin{array}{lllll} & \text { Res.Df } & \text { Df } & F & \operatorname{Pr}(>F) \\ 1 & 97 & & & \\ 2 & 98 & -1 & 0.9697 & 0.3272\end{array}$

Granger causality test

Mode1 1: SVY.ts Lags(SVY.ts, 1:1) + Lags (DCY.ts, 1:1) Mode1 2: SVY.ts Lags (SVY.ts, 1:1)

$\begin{array}{lllll} & \text { Res.Df } & \text { Df } & F & \operatorname{Pr}(>F) \\ 1 & 97 & & & \\ 2 & 98 & -1 & 0.0489 & 0.8255\end{array}$




\section{TIME SERIES ANALYSIS - GRANGER CAUSALITY}

\section{INTRO}

2. Clefting IN $\mathrm{BP}$

3. DATA

4. GRANGER CAUSALITY

5. RESULTS

6. CONCLUSION

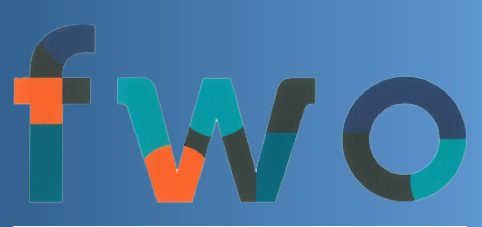

KU LEUVEN
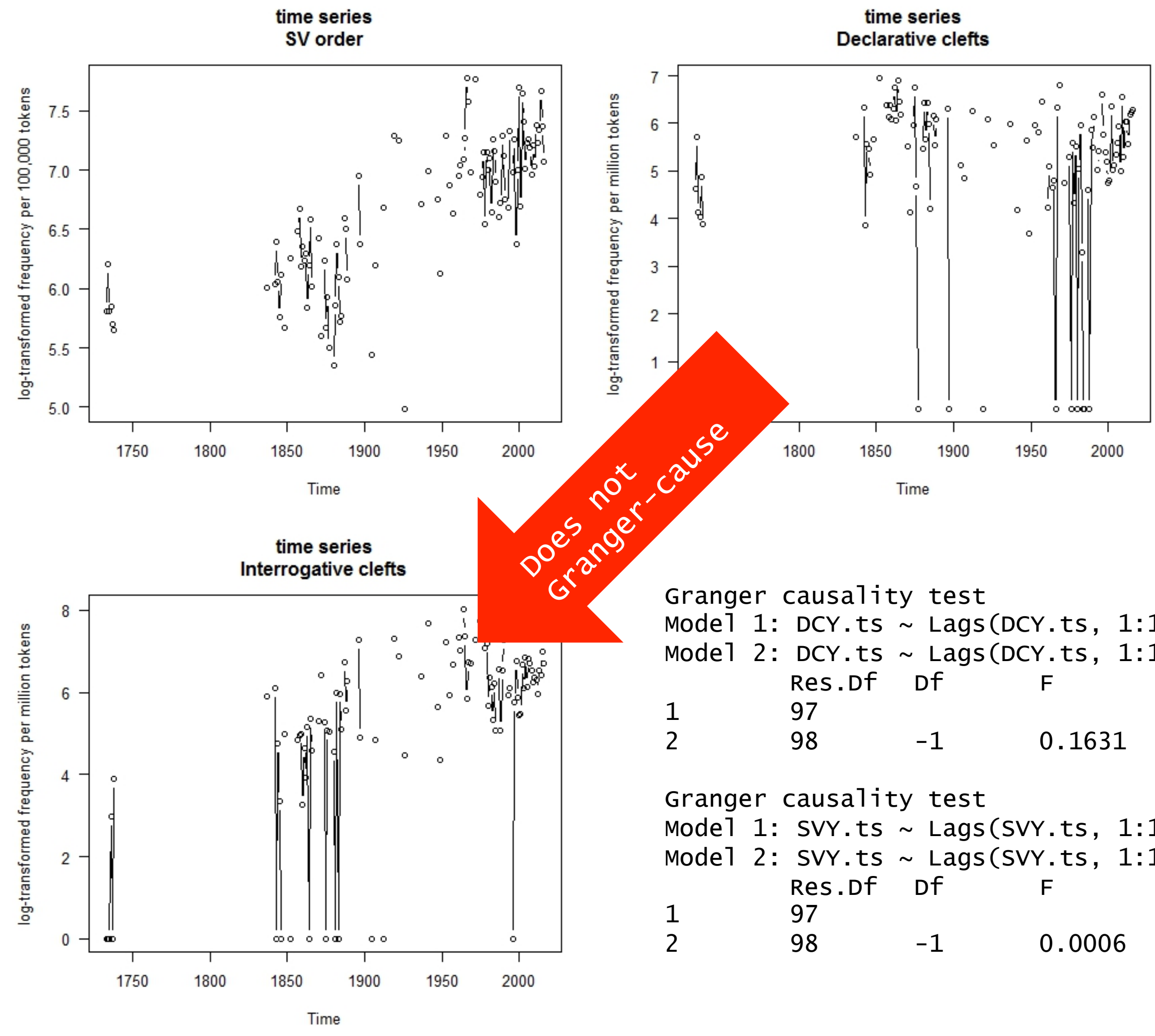

Granger causality test

Mode1 1: DCY.ts Lags(DCY.ts, 1:1) + Lags (SVY.ts, 1:1)

Mode1 2: DCY.ts Lags (DCY.ts, 1:1)

$1 \quad 97$ Res.Df Df $F \quad \operatorname{Pr}(>F)$

1
2

$-1$

0.1631

0.6872

Granger causality test

Mode1 1: SVY.ts Lags(SVY.ts, 1:1) + Lags (DCY.ts, 1:1)

Mode1 2: SVY.ts $\sim \operatorname{Lags}(S V Y . t s, 1: 1$ )

Res.Df Df $F \quad \operatorname{Pr}(>F)$

$\begin{array}{lllll}1 & 97 & & 0.0006 & 0.9806\end{array}$ 


\section{CONCLUSION}

1. INTRO

2. CleFTING IN $\mathrm{BP}$

3. DATA

4. GRANGER CAUSALITY

5. RESULTS

6. CONCLUSION
- Summary:

- SV-order Granger-causes interrogative clefts, but not the other way around (H3)

- SV-order does not Granger-cause declarative clefts

- Declarative clefts do not Granger-cause interrogative clefts (but: this may be due to the low frequency of declarative clefts in present tense)

- Is this causation? Some caveats:

- Granger-causality does not imply strict causality. There may be deeper causal factors 


\section{CONCLUSION}

1. INTRO

2. CLEFTING IN $\mathrm{BP}$

3. DATA

4. GRANGER

CAUSALITY

5. RESULTS

6. CONCLUSION

- We hypothesize the following scenario:

- Clefts are a compensating strategy for loss of VS word order. But how much functional variation is there in these clefts?

- Questions make more eager use of this strategy because it has stronger implications for discourse structure

- Over time, the cleft-wh constituent became a co-marker of interrogative mood

- This ties in with other cases of compensation-by-already-existing-strategies, see Van de Velde (2014) on 'Degeneracy'. 